\title{
Omani Stakeholders' Preferences for Educational Placement of Students with Disabilities
}

\author{
Jalal H. Hussien* \\ Madison Metropolitan School \\ District, Wisconsin, USA
}

\author{
Abdelhafez Q. Al-Shayeb \\ $\mathrm{Al}$ al-Bayt University, \\ Jordan
}

\author{
Ibrahim Al-Qaryouti \\ Sultan Qaboos University, \\ Sultanate of Oman
}

Received: 31/3/2015

Revised: 5/5/2015

Accepted: $18 / 5 / 2015$

\begin{abstract}
The purpose of the current study was to survey the stakeholders' opinions of the best educational placement setting for students with disabilities in the Sultanate of Oman. Two thousand four hundred and thirty stakeholders participated in this study. The findings provided evidence that the majority of the Omani stakeholders prefer educating students with disabilities in regular schools over separate facilities. In addition, the stakeholders' preference on the continuum of placement options varied significantly. The results also suggested that the stakeholders' preference for educating students in the regular school setting versus a separate facility varied according to the type of disability. Moreover, a significant association between the stakeholders' role and their preference of educational placement setting for students with disabilities was found. However, the findings revealed that there was no significant relationship between the stakeholders' gender and their educational settings preference. Finally, educational services for children with disabilities in Oman were discussed and suggestions were provided to improve these services.
\end{abstract}

Keywords: Educational placement, inclusive classrooms, students with disabilities, Sultanate of Oman.

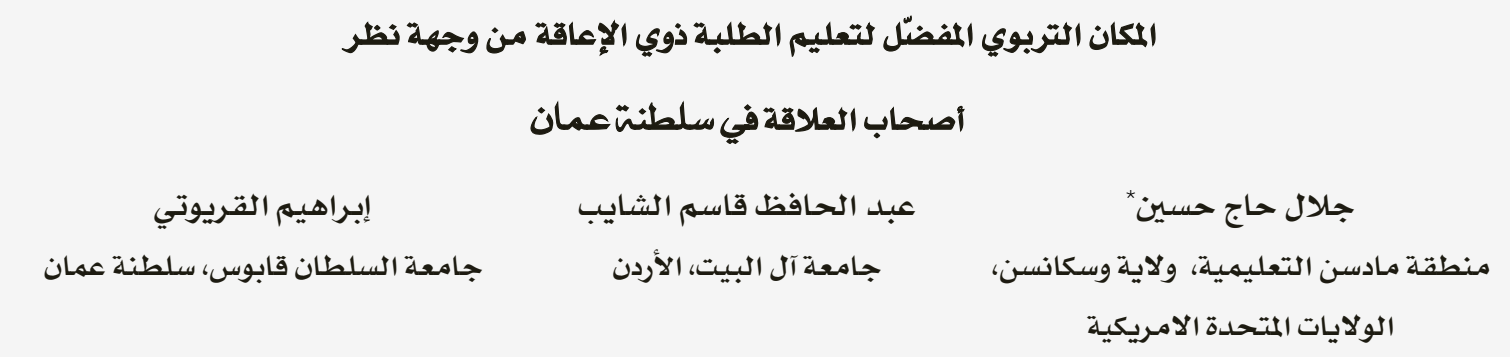

مستخلص: هدفت الدراسـة الحالية إلى استطلاع آراء ذوي العلاقة حول المكان التربوي المفضلّ لديهم لتعليم الطلبة

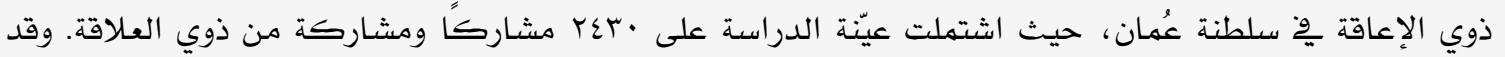
أشارت النتائج إلى أن معظم المشاركين يوْ الدراسة من ذوي العلاقة يعتقدون أن مدارس التعليم العام هي المكان الأفضل لتعليم الطلبة ذوي الإعاقة مقارنة ِِخ البيئات التربويَّة . وأسفرت النتائج عن وجود فروق جوهرية بين آراء المشـاركين فيما يتعلق بالبيئاتِ التربويَّة التي يفضلونها. وتبيّن أيضاً أن تفضيل المشاركين لمدارس التعليم العام مقابل البيئاتِ التربويَّة التعليم الطلبة ذوي الإعاقة يختلف باختلاف نوع الإعاقة. بالإضافة إلى ذلك، تبيّن وجود علاقة بين

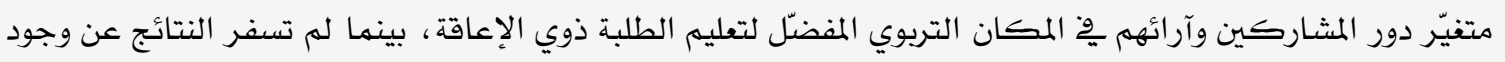
علاقة بين متغيّر جنس المشاركين وآرائهم ٌِِ المكان التربوي المفضلّ لتعليم الطلبة ذوي الإعاقة. وانتهت الدراسة

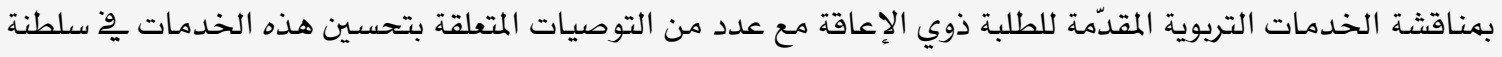
عُمان. الكلمات المفتاحية: المكان التربوي، الصفوف الشاملة ، الطلبة ذوي الإعاقة، سلطنة عُمان. 
Special education services are relatively new in the Sultanate of Oman. In 2008, the Sultanate signed the International Agreement on the Rights of Persons with Disabilities for Education in an Inclusive Educational Setting (Ministry of Education, 2008). Inclusive education refers to teaching students with disabilities in their neighborhood school within the regular classroom with their peers without disabilities (Rafferty, Boettcher, \& Griffin, 2001). The Ministry of Education provides educational services for students with disabilities in special education classes in many public schools as well as in special education schools (Al-Balushi, Al-Badi, \& Ali, 2011; Weber, 2012).

Oman has been in the process of reforming its educational system and significant efforts have been made towards achieving this goal (Haj Hussien \& Al-Qaryouti, 2014). The Ministry of Education in Oman aims to create inclusive schools (Ministry of Education, 2008). The previous literature consistently showed that the attitudes of the principals (Balboni \& Pedrabissi, 2000; Dyson, Howes, \& Roberts, 2004; Kugelmass \& Ainscow,2004; Semmel, 1986; Villa, Thousand, Meyers, \& Navin, 1996), teachers (Ahsan, Sharma \& Deppeler, 2012; Avramidis, Balyliss, \& Burden, 2000; Avramidis \& Norwich, 2002; Emam \& Hassan, 2011; Haj Hussien \& Al-Qaryouti, 2014; Sari, Celikoz, \& Secer, 2009), parents (Gilmore, Campbell, \& Cuskelly, 2003; Grove \& Fisher, 1999; Tafa \& Manolitsis, 2003), and students (Gannon \& McGilloway, 2009; Georgiadi, Kalyva, Kourkoutas, \& Tsakiris, 2012; Haj Hussien \& Al-Qaryouti, 2015; Miller, Garriott, \& Mershon, 2005; Morin, Crocker, Beaulieu-Bergeron, \& Caron, 2013; Panagiotou et al., 2008; Papaioannou, Evaggelinou, \& Block, 2014; Patel \& Rose, 2014) play a major role in developing and implementing inclusive education successfully.

Teachers, parents, students, and administrators are the critical stakeholders and play a vital role in creating inclusive schools; considering their opinions is critical to the success of systematic school reform (Hunt \& McDonnell, 2007; Wang, 2009). The purpose of the current study was to survey the Omani stakeholders' opinions of the best educational placement for students with disabilities. More specifically the current study aimed to answer the following questions:

1. Is the stakeholders' gender associated with their preference of educational placement setting for students with disabilities?

2. Is the stakeholders' role associated with their preference of educational placement setting for students with disabilities?

3. What is the pattern of the stakeholders' preference of educational placement settings for students with disabilities?

4. Do the differences between percentages of each category of stakeholders' responses on each pair of educational placement for students with disabilities differ significantly?

5. What is the stakeholders' educational placement preference (separate facilities vs. regular school) for students with disabilities?

6. What is the stakeholders' educational placement preference (separate facilities vs. regular school) for each type of disability?

7. Does the stakeholders' educational placement preference for students with disabilities differ significantly according to the student's type of disability?

\section{Context of the study}

The Ministry of Education in Oman aims to create inclusive schools (Ministry of Education, 2008). Currently a total of 5,325 individuals with disabilities are receiving services in Oman. These services are provided by the Ministry of Education, and the Ministry of Social Development. The Ministry of Education provides educational services in special education classes in 155 public schools for a total of 1,565 students; 1,262 students with intellectual disabilities and 303 students with hearing impairments (Ministry of Education, 2015). The number of students with disabilities enrolled in special education classes in public school has increased steadily over the last ten school years. 
students in the three special education schools; 192 students enrolled in the Hope School for Students with Hearing Disability, 213 students enrolled in the School of Intellectual Disability, and 137 students enrolled in Omar Ben Alkatab for Students with Visual Impairments (Ministry of Education, 2015).

The Ministry of Social Development provides services for a total of 3,218 individuals with disabilities; among them 2,180 individuals are enrolled in 25 governmental centers, 605 individuals with disabilities are enrolled in 13 private centers, and 433 individuals with disabilities are enrolled in 10 nonprofit associations' centers (Ministry of Social Development, 2015).

\section{Method}

\section{Participants}

A total of 3,000 questionnaires were sent to the administrators of the public schools in Sultanate Oman in various provinces; 2,430 stakeholders (1,211 males \& 1,219 females), representing all grade levels, volunteered to complete the questionnaires. The sample involved 703 regular teachers (359 males \& 344 females), 225 special education teachers (36 males \& 189 females), 160 social workers (64 males \& 96 females), 318 principals (169 males \& 149 females), 234 parents of students with disabilities (143 males \& 91 females), 386 parents of students without disabilities (244 males \& 142 females), and 404 students (196 males \& 208 females). Table 1 shows the distribution of the participants according to province by stakeholders.

\section{Variables}

Stakeholders: This variable involved regular teachers, special education teachers, social workers, principals, parents of students with disabilities, parents of students without disabilities, and students.

Gender: This variable involved males and females.

Educational placement: This variable involved separate facilities, self-contained class, resource room, and general education classroom.

Types of disabilities: This variable involved intellectual disability, autism, emotional and behavioral disability, hearing impairment, other health impairment, specific learning disability, vision impairment, speech and language disability, \& physical disability.

\section{Stakeholder's Opinion of the Best Placement for Students with Disabilities Questionnaire:}

The authors developed this questionnaire to identify the stakeholders' opinions of the best educational placement for students with disabilities. This questionnaire developed by the authors was based on the special education services continuum from the most segregated environment to the most inclusive. A continuum of placement options available for students with disabilities is necessary to meet the needs of all special education students (Kauffman, Bantz, \& McCullough, 2002). The placements from the most segregated to the most inclusive are the following: a) separate facilities, b) self-contained class, c) resource room, and d) general education.

Table 1

Participants' distribution according to province by stakeholders

\begin{tabular}{|c|c|c|c|c|c|c|c|c|}
\hline \multicolumn{9}{|c|}{ Stakeholders } \\
\hline Province & $\begin{array}{l}\text { Regular } \\
\text { teacher }\end{array}$ & $\begin{array}{c}\text { Special } \\
\text { education } \\
\text { teacher }\end{array}$ & $\begin{array}{c}\text { Social } \\
\text { worker }\end{array}$ & Principal & $\begin{array}{l}\text { Parents of } \\
\text { students } \\
\text { with disa- } \\
\text { bilities }\end{array}$ & $\begin{array}{l}\text { Parents of stu- } \\
\text { dents without } \\
\text { disabilities }\end{array}$ & Student & Total \\
\hline Muscat & 404 & 179 & 33 & 48 & 168 & 76 & 93 & 1001 \\
\hline Al Batinah Janoob & 56 & 12 & 7 & 30 & 15 & 36 & 46 & 202 \\
\hline Al Batinah Shamal & 78 & 8 & 8 & 48 & 18 & 78 & 85 & 323 \\
\hline Al Dakhiliyah & 21 & 4 & 3 & 15 & 17 & 31 & 31 & 122 \\
\hline $\begin{array}{l}\text { Ash Sharqiyah Ja- } \\
\text { noob }\end{array}$ & 5 & 9 & 1 & 10 & 5 & 6 & 5 & 41 \\
\hline $\begin{array}{l}\text { Ash Sharqiyah Sha- } \\
\text { mal }\end{array}$ & 26 & 4 & 7 & 28 & 2 & 28 & 25 & 120 \\
\hline Al Burimi & 16 & 1 & 8 & 16 & 3 & 14 & 12 & 70 \\
\hline Al Dhirah & 12 & 3 & 7 & 12 & 4 & 23 & 15 & 76 \\
\hline Dhofar & 59 & 4 & 61 & 83 & 0 & 60 & 60 & 327 \\
\hline Al Wusta & 11 & 1 & 10 & 8 & 2 & 13 & 14 & 59 \\
\hline Musandam & 15 & 0 & 15 & 20 & 0 & 21 & 18 & 89 \\
\hline Total & 703 & 225 & 160 & 318 & 234 & 386 & 404 & 2430 \\
\hline
\end{tabular}


The questionnaire included the following ten questions:

1. In your opinion what is the best educational placement for students with intellectual disabilities?

2. In your opinion what is the best educational placement for students with autism?

3. In your opinion what is the best educational placement for students with emotional and behavioral disabilities?

4. In your opinion what is the best educational placement for students with a hearing impairment?

5. In your opinion what is the best educational placement for students with other health impairments?

6. In your opinion what is the best educational placement for students with specific learning disabilities?

7. In your opinion what is the best educational placement for students with a visual impairment?

8. In your opinion what is the best educational placement for students with speech and language disabilities?

9. In your opinion what is the best educational placement for students with physical disabilities?

10. In your opinion what is the best educational placement for students with disabilities?

Each question was followed by the four educational placements:

- ( ) Full-time outside the regular school

- ( ) Full-time in special education classrooms in the regular school

- ( ) Part-time in the regular classroom with part-time in a resource room

- ( ) Full-time in the regular classroom with other support services provided there

The questionnaire was examined by 4 experts, comprising of two experts in measurement and psychometric theory and two experts in special education. The four experts agreed that the questionnaire was written in clear and precise language as well as measuring what it intended to measure.
Procedure: The purpose of the study was explained to the participants with the emphasis on the importance of them expressing their personal opinion while considering that there are no right or wrong responses. Finally, the participants were asked to select the best educational placement among the four placements options by marking their selection with a tick $(\checkmark)$.

\section{Results}

The purpose of the current study was to survey the stakeholders' opinions of the best educational placement setting for students with disabilities in the Sultanate of Oman. Two thousand four hundred and thirty stakeholders participated in the study. Frequencies and percentages, a chi-square test of independence and a chi-square test of goodness of fit were performed to answer the questions of the study. Each research question and its findings are presented below.

Question 1: What is the pattern of the stakeholders' preference of educational placement settings for students with disabilities?

The frequencies and percentages of stakeholders' responses on educational placement preference were calculated and are presented in Table 3. In addition, a chi-square test of goodness of fit was performed to determine whether the four educational settings (separate facilities, self-contained class, resource room, and general education) for students with disabilities were equally selected by the stakeholders. The findings showed that the stakeholders' selection of the four educational placement settings for students with disabilities were not equally distributed in the population, $X^{2}(3,2240)$ $=541.95, p<0.000$. The results shown in Table 2 indicate that $43.3 \%, 29 \%, 12 \%$, and $15.8 \%$ of the stakeholders selected separate setting, selfcontained, resource room, and general education, respectively, as the best educational settings for educating students with disabilities. 
Table 2

Educational placement preference by the role of the stakeholder and gender

\begin{tabular}{|c|c|c|c|c|c|c|c|}
\hline \multirow[b]{2}{*}{ Gender } & \multirow[b]{2}{*}{ Stakeholder } & \multirow[b]{2}{*}{ Descriptive measure } & \multicolumn{3}{|c|}{ Educational Setting Preference } & \multirow[b]{2}{*}{$\begin{array}{l}\text { General } \\
\text { education }\end{array}$} & \multirow[b]{2}{*}{ Total } \\
\hline & & & $\begin{array}{l}\text { Separate } \\
\text { facilities }\end{array}$ & $\begin{array}{l}\text { Self- } \\
\text { contained } \\
\text { class }\end{array}$ & $\begin{array}{l}\text { Resource } \\
\text { room }\end{array}$ & & \\
\hline \multirow[t]{16}{*}{ Male } & \multirow[t]{2}{*}{ Regular Teacher } & Count & 149 & 108 & 34 & 30 & 321 \\
\hline & & $\%$ within Source & $46.4 \%$ & $33.6 \%$ & $10.6 \%$ & $9.3 \%$ & $100.0 \%$ \\
\hline & \multirow{4}{*}{$\begin{array}{l}\text { Special Educa- } \\
\text { tion Teacher } \\
\text { Social Worker }\end{array}$} & Count & 18 & 7 & 9 & 2 & 36 \\
\hline & & $\%$ within Source & $50.0 \%$ & $19.4 \%$ & $25.0 \%$ & $5.6 \%$ & $100.0 \%$ \\
\hline & & Count & 17 & 22 & 3 & 15 & 57 \\
\hline & & \% within Source & $29.8 \%$ & $38.6 \%$ & $5.3 \%$ & $26.3 \%$ & $100.0 \%$ \\
\hline & \multirow[t]{2}{*}{ Principal } & Count & 63 & 40 & 24 & 23 & 150 \\
\hline & & \% within Source & $42.0 \%$ & $26.7 \%$ & $16.0 \%$ & $15.3 \%$ & $100.0 \%$ \\
\hline & \multirow{2}{*}{$\begin{array}{l}\text { Parents of stu- } \\
\text { dents with dis- } \\
\text { abilities }\end{array}$} & Count & 45 & 28 & 19 & 37 & 129 \\
\hline & & \% within Source & $34.9 \%$ & $21.7 \%$ & $14.7 \%$ & $28.7 \%$ & $100.0 \%$ \\
\hline & \multirow{2}{*}{$\begin{array}{l}\text { Parents of stu- } \\
\text { dents without } \\
\text { disabilities }\end{array}$} & Count & 98 & 53 & 40 & 40 & 231 \\
\hline & & $\%$ within Source & $42.4 \%$ & $22.9 \%$ & $17.3 \%$ & $17.3 \%$ & $100.0 \%$ \\
\hline & \multirow[t]{2}{*}{ Student } & Count & 99 & 41 & 17 & 37 & 194 \\
\hline & & \% within Source & $51.0 \%$ & $21.1 \%$ & $8.8 \%$ & $19.1 \%$ & $100.0 \%$ \\
\hline & \multirow[t]{2}{*}{ Total } & Count & 489 & 299 & 146 & 184 & 1118 \\
\hline & & $\%$ within Source & $43.7 \%$ & $26.7 \%$ & $13.1 \%$ & $16.5 \%$ & $100.0 \%$ \\
\hline \multirow[t]{16}{*}{ Female } & \multirow[t]{2}{*}{ Regular Teacher } & Count & 154 & 102 & 28 & 25 & 309 \\
\hline & & $\%$ within Source & $49.8 \%$ & $33.0 \%$ & $9.1 \%$ & $8.1 \%$ & $100.0 \%$ \\
\hline & \multirow{4}{*}{$\begin{array}{l}\text { Special Educa- } \\
\text { tion Teacher } \\
\text { Social Worker }\end{array}$} & Count & 76 & 45 & 25 & 42 & 188 \\
\hline & & \% within Source & $40.4 \%$ & $23.9 \%$ & $13.3 \%$ & $22.3 \%$ & $100.0 \%$ \\
\hline & & Count & 30 & 52 & 5 & 3 & 90 \\
\hline & & \% within Source & $33.3 \%$ & $57.8 \%$ & $5.6 \%$ & $3.3 \%$ & $100.0 \%$ \\
\hline & \multirow[t]{2}{*}{ Principal } & Count & 50 & 54 & 12 & 25 & 141 \\
\hline & & \% within Source & $35.5 \%$ & $38.3 \%$ & $8.5 \%$ & $17.7 \%$ & $100.0 \%$ \\
\hline & \multirow{2}{*}{$\begin{array}{l}\text { Parents of stu- } \\
\text { dents with dis- } \\
\text { abilities }\end{array}$} & Count & 32 & 25 & 7 & 15 & 79 \\
\hline & & $\%$ within Source & $40.5 \%$ & $31.6 \%$ & $8.9 \%$ & $19.0 \%$ & $100.0 \%$ \\
\hline & \multirow{2}{*}{$\begin{array}{l}\text { Parents of stu- } \\
\text { dents without } \\
\text { disabilities }\end{array}$} & Count & 56 & 31 & 15 & 28 & 130 \\
\hline & & \% within Source & $43.1 \%$ & $23.8 \%$ & $11.5 \%$ & $21.5 \%$ & $100.0 \%$ \\
\hline & Student & Count & 82 & 42 & 30 & 31 & 185 \\
\hline & & $\%$ within Source & $44.3 \%$ & $22.7 \%$ & $16.2 \%$ & $16.8 \%$ & $100.0 \%$ \\
\hline & Total & Count & 480 & 351 & 122 & 169 & 1122 \\
\hline & & \% within Source & $42.8 \%$ & $31.3 \%$ & $10.9 \%$ & $15.1 \%$ & $100.0 \%$ \\
\hline Total & Regular Teacher & Count & 303 & 210 & 62 & 55 & 630 \\
\hline & & $\%$ within Source & $48.1 \%$ & $33.3 \%$ & $9.8 \%$ & $8.7 \%$ & $100.0 \%$ \\
\hline & Special Educa- & Count & 94 & 52 & 34 & 44 & 224 \\
\hline & tion Teacher & \% within Source & $42.0 \%$ & $23.2 \%$ & $15.2 \%$ & $19.6 \%$ & $100.0 \%$ \\
\hline & Social Worker & Count & 47 & 74 & 8 & 18 & 147 \\
\hline & & $\%$ within Source & $32.0 \%$ & $50.3 \%$ & $5.4 \%$ & $12.2 \%$ & $100.0 \%$ \\
\hline & Principal & unt & 113 & 94 & 36 & 48 & 291 \\
\hline & & \% within Source & $38.8 \%$ & $32.3 \%$ & $12.4 \%$ & $16.5 \%$ & $100.0 \%$ \\
\hline & Parents of stu- & Count & 77 & 53 & 26 & 52 & 208 \\
\hline & $\begin{array}{l}\text { dents with dis- } \\
\text { abilities }\end{array}$ & $\%$ within Source & $37.0 \%$ & $25.5 \%$ & $12.5 \%$ & $25.0 \%$ & $100.0 \%$ \\
\hline & Parents of stu- & Count & 154 & 84 & 55 & 68 & 361 \\
\hline & $\begin{array}{l}\text { dents without } \\
\text { disabilities }\end{array}$ & $\%$ within Source & $42.7 \%$ & $23.3 \%$ & $15.2 \%$ & $18.8 \%$ & $100.0 \%$ \\
\hline & Student & Count & 181 & 83 & 47 & 68 & 379 \\
\hline & & $\%$ within Source & $47.8 \%$ & $21.9 \%$ & $12.4 \%$ & $17.9 \%$ & $100.0 \%$ \\
\hline Total & & Count & 969 & 650 & 268 & 353 & 2240 \\
\hline & & $\%$ within Source & $43.3 \%$ & $29.0 \%$ & $12.0 \%$ & $15.8 \%$ & $100.0 \%$ \\
\hline
\end{tabular}


Question 2: Is the stakeholders' gender associated with their preference of educational placement setting for students with disabilities?

The chi-square test of independence was performed to examine the association between the stakeholders' gender and their preference of educational placement setting (separate facilities, self-contained class, resource room, and general education) for students with disabilities. The results revealed no association between the stakeholders' gender (male \& female) and their preference of educational placement setting for students with disabilities, $X^{2}(3,2240)=3.02, p>.05$.

Question 3: Is the stakeholders' role associated with their preference of educational placement setting for students with disabilities?

The chi-square test of independence was performed to examine the association between the stakeholders' role (regular teachers, special education teachers, social workers, principals, parents of students with disabilities, parents of students without disabilities, and students) and their preference of educational placement setting (separate facilities, self-contained class, resource room, and general education) for students with disabilities. A significant association between stakeholders' role and their preference of educational placement setting for students with disabilities was revealed, $X^{2}$ $(18,2240)=105.85, p<.0001$.

Based on the results shown in Table 2 and Figure 1, it appears that the stakeholders preferred the separate facilities setting followed by the self-contained class setting, with the exception of the social workers, who preferred the self-contained class setting firstly, followed by the separate facilities setting. Moreover, it seems that the resource room setting was selected by stakeholders as the least preferred setting, with the exception of the regular teachers who selected the general education setting as the least preferred option.

Question 4: Do the differences between percentages of each category of stakeholders' responses on each pair of educational placement for students with disabilities differ significantly?

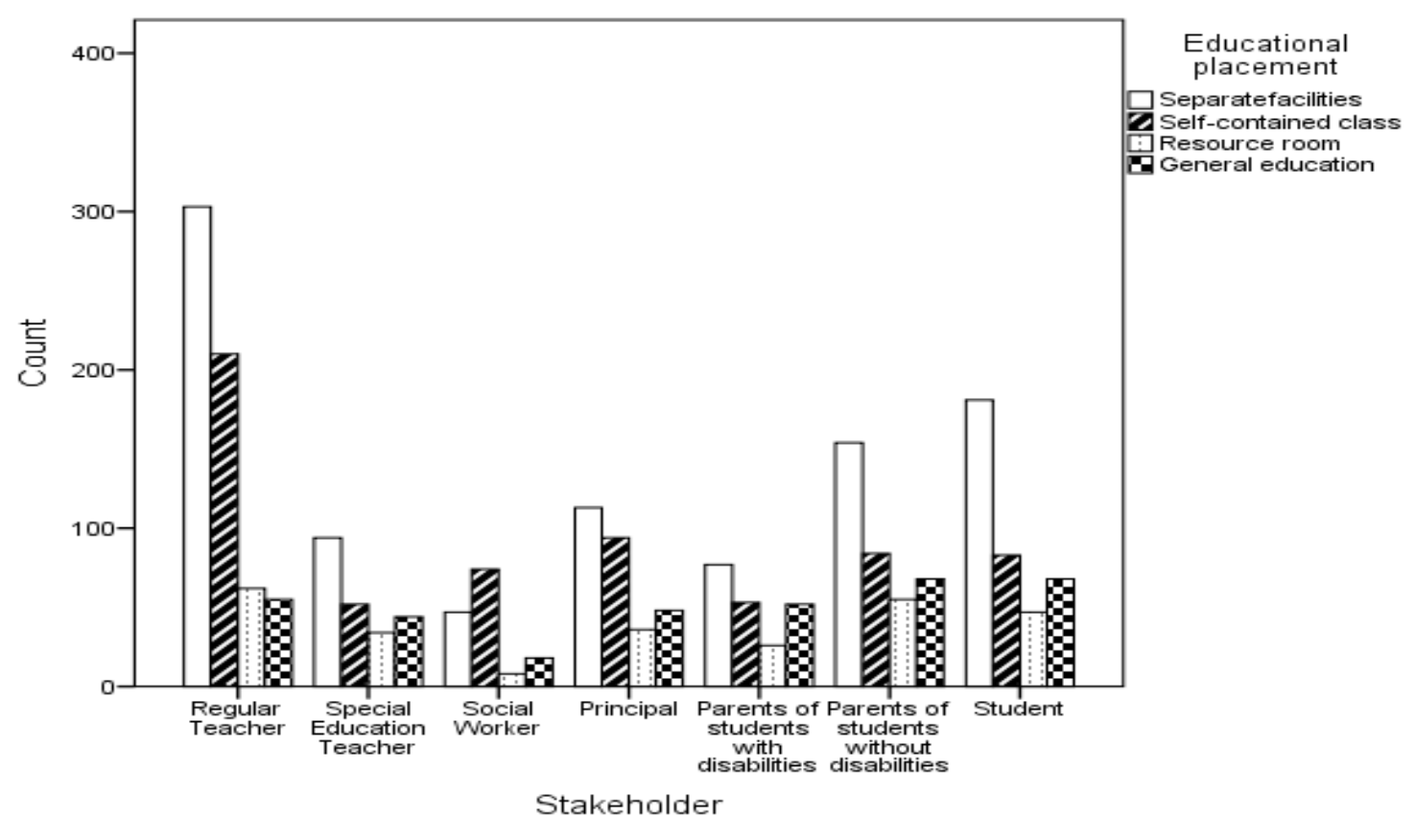

Figure 1

Educational placement preference by the role of the stakeholder 
The chi-square test of goodness of fit was performed to examine the differences between percentages for each category of stakeholders' responses on each pair of educational placement separately. These results are presented below according to each category of stakeholders.

Regular classroom teachers: The results in Table 3 indicate that a significantly higher proportion $(p<.001)$ of regular classroom teachers selected separate facilities as the best educational placement setting for students with disabilities compared with any other educational placement setting. In addition, a significantly higher proportion $(p<.001)$ of regular classroom teachers selected self-contained class as the best educational placement setting for students with disabilities compared with resource room and general education classroom settings. However, there was no significant difference $(p=.05)$ between the proportion of regular classroom teachers who selected the resource room setting and the propor- tion of those teachers who selected the general education classroom setting.

Special education teachers: The results in Table 4 indicate that a significantly higher proportion $(p<.001)$ of special education teachers selected separate facilities as the best educational placement setting for students with disabilities compared with any other educational placement setting. In addition, a significantly higher proportion $(p<.05)$ of special education teachers selected self-contained class as a better educational placement setting for students with disabilities compared with the resource room setting. However, there was no significant difference $(p=.05)$ between the proportion of special education teachers who selected self-contained class setting and the proportion of those teachers who selected general education classroom setting. Similarly, there was no significant difference $(p=.05)$ between the proportion of special education teachers who selected the resource room setting and the proportion of those teachers who selected the general education classroom.

Table 3

Results of the chi-square on the difference between percentages of regular classroom teachers' responses for each pair of educational placement

\begin{tabular}{|c|c|c|c|c|c|c|}
\hline Setting & Observed N & Expected N & Residual & Chi-Square & Df & Asymp.sig. \\
\hline Separate facilities & 303 & 256.5 & 46.5 & 16.860 & 1 & .000 \\
\hline Self-contained class & 210 & 256.5 & -46.5 & & & \\
\hline Total & 513 & & & & & \\
\hline Separate facilities & 303 & 182.5 & 120.5 & 159.126 & 1 & .000 \\
\hline Resource room & 62 & 182.5 & -120.5 & & & \\
\hline Total & 365 & & & & & \\
\hline Separate facilities & 303 & 179.0 & 124.0 & 171.799 & 1 & .000 \\
\hline General education & 55 & 179.0 & -124.0 & & & \\
\hline Total & 358 & & & & & \\
\hline Self-contained class & 210 & 136.0 & 74.0 & 80.529 & 1 & .000 \\
\hline Resource room & 62 & 136.0 & -74.0 & & & \\
\hline Total & 272 & & & & & \\
\hline Self-contained class & 210 & 132.5 & 77.5 & 90.660 & 1 & .000 \\
\hline General education & 55 & 132.5 & -77.5 & & & \\
\hline Total & 265 & & & & & \\
\hline Resource room & 62 & 58.5 & 3.5 & 0.419 & 1 & .518 \\
\hline General education & 55 & 58.5 & -3.5 & & & \\
\hline Total & 117 & & & & & \\
\hline
\end{tabular}

Table 4

Results of the Chi-Square on the difference between percentages of special education teachers' responses for each pair of educational placement

\begin{tabular}{lcccccc}
\hline Setting & Observed N & Expected N & Residual & Chi-Square & Df & Asymp.sig. \\
\hline Separate facilities & 94 & 73.0 & 21.0 & 12.082 & 1 & .001 \\
Self-contained class & 52 & 73.0 & -21.0 & & & \\
Total & 146 & & & & & \\
Separate facilities & 94 & 64.0 & 30.0 & 28.125 & 1 & .000 \\
Resource room & 34 & 64.0 & -30.0 & & & \\
Total & 128 & & & & & \\
Separate facilities & 94 & 69.0 & 25.0 & 18.116 & 1 & .000 \\
General education & 44 & 69.0 & -25.0 & & & \\
Total & 138 & & & & &
\end{tabular}


Table 4

Results of the Chi-Square on the difference between percentages of

\begin{tabular}{lcccccc}
\multicolumn{7}{c}{ special education teachers' responses for each pair of educational placement } \\
\hline Setting & Observed N & Expected N & Residual & Chi-Square & Df & Asymp.sig. \\
\hline Self-contained class & 52 & 43.0 & 9.0 & 3.767 & 1 & .05 \\
Resource room & 34 & 43.0 & -9.0 & & & \\
Total & 86 & & & & & \\
Self-contained class & 52 & 48.0 & 4.0 & 0.667 & & .414 \\
General education & 44 & 48.0 & -4.0 & & & \\
Total & 96 & & & & & \\
Resource room & 34 & 39.0 & -5.0 & 1.282 & & .258 \\
General education & 44 & 39.0 & 5.0 & & & \\
Total & 78 & & & & & \\
\hline
\end{tabular}

Social workers: The results in Table 5 indicate that a significantly higher proportion $(p<.01)$ of social workers selected self-contained class as the best educational placement setting for students with disabilities compared with any other educational placement setting. In addition, a significantly higher proportion $(p<$ .001) of social workers preferred separate facilities as a better educational placement setting for students with disabilities compared with the resource room and general education classroom settings. The results also revealed that a significantly higher proportion $(p<.05)$ of social workers preferred the general education classroom setting as a better educational placement setting for students with disabilities compared with the resource room setting.

Principals: The results in Table 6 indicate that a significantly higher proportion $(p<.001)$ of principals selected separate facilities as the best educational placement setting for students with disabilities compared with the resource room, and general education classroom settings. On the other hand, there was no significant difference $(p=.05)$ between the proportion of principals who selected separate facilities and the proportion of those principals who selected self-contained class setting for students with disabilities. The results also indicate that a significantly higher proportion ( $p$ $<.001$ ) of principals selected self-contained class as the best educational placement setting for students with disabilities compared with the resource room and general education classroom settings. It has also been revealed that there was no significant difference $(p=$ .05) between the proportion of principals who selected resource room and general education classroom settings.

Table 5

Results of the Chi-Square on the difference between percentages of social workers' responses for each pair of educational placement

\begin{tabular}{|c|c|c|c|c|c|c|}
\hline Setting & Observed N & Expected N & Residual & Chi-Square & Df & Asymp. sig. \\
\hline Separate facilities & 47 & 60.5 & -13.5 & 6.025 & 1 & .014 \\
\hline Self-contained class & 74 & 60.5 & 13.5 & & & \\
\hline Total & 121 & & & & & \\
\hline Separate facilities & 47 & 27.5 & 19.5 & 27.655 & 1 & .000 \\
\hline Resource room & 8 & 27.5 & -19.5 & & & \\
\hline Total & 55 & & & & & \\
\hline Separate facilities & 47 & 32.5 & 14.5 & 12.938 & 1 & .000 \\
\hline General education & 18 & 32.5 & -14.5 & & & \\
\hline Total & 65 & & & & & \\
\hline Self-contained class & 74 & 41.0 & 33.0 & 53.122 & 1 & .000 \\
\hline Resource room & 8 & 41.0 & -33.0 & & & \\
\hline Total & 82 & & & & & \\
\hline Self-contained class & 74 & 46.0 & 28.0 & 34.087 & 1 & .000 \\
\hline General education & 18 & 46.0 & -28.0 & & & \\
\hline Total & 92 & & & & & \\
\hline Resource room & 8 & 13.0 & -5.0 & 3.846 & 1 & .050 \\
\hline General education & 18 & 13.0 & 5.0 & & & \\
\hline Total & 26 & & & & & \\
\hline
\end{tabular}

Table 6

Results of the Chi-square on the difference between percentages of principals' responses for each pair of educational placement

\begin{tabular}{lrrrrrr}
\hline \multicolumn{1}{c}{ Setting } & Observe N & Expected N & Residual & Chi-Square & \multicolumn{1}{c}{ df } & Asymp. sig. \\
\hline Separate facilities & 113 & 103.5 & 9.5 & 1.744 & 1 & .187 \\
Self-contained class & 94 & 103.5 & -9.5 & & & \\
Total & 207 & & & & & \\
Separate facilities & 113 & 74.5 & 38.5 & 39.792 & 1 & .000
\end{tabular}


Table 6

Results of the Chi-square on the difference between percentages of principals' responses for each pair of educational placement

\begin{tabular}{|c|c|c|c|c|c|c|}
\hline Setting & Observe N & Expected N & Residual & Chi-Square & $\mathrm{df}$ & Asymp. sig. \\
\hline Resource room & 36 & 74.5 & -38.5 & & & \\
\hline Total & 149 & & & & & \\
\hline Separate facilities & 113 & 80.5 & 32.5 & 26.242 & 1 & .000 \\
\hline General education & 48 & 80.5 & -32.5 & & & \\
\hline Total & 161 & & & & & \\
\hline Self-contained class & 94 & 65.0 & 29.0 & 25.877 & 1 & .000 \\
\hline Resource room & 36 & 65.0 & -29.0 & & & \\
\hline Total & 130 & & & & & \\
\hline Self-contained class & 94 & 71.0 & 23.0 & 14.901 & 1 & .000 \\
\hline General education & 48 & 71.0 & -23.0 & & & \\
\hline Total & 142 & & & & & \\
\hline Resource room & 36 & 42.0 & -6.0 & 1.714 & 1 & .190 \\
\hline General education & 48 & 42.0 & 6.0 & & & \\
\hline Total & 84 & & & & & \\
\hline
\end{tabular}

Parents of students with disabilities: The results in Table 7 indicate that a significantly higher proportion $(p<.05)$ of parents of students with disabilities selected separate facilities as the best educational placement setting for students with disabilities compared with any other educational placement setting. In addition, a significantly higher proportion $(p<$ .01 ) of parents of students with disabilities selected self-contained class as the best educational placement setting for students with disabilities compared with the resource room setting, but not the general education classroom setting. The results also indicate that a significantly higher proportion $(p<.01)$ of parents of students with disabilities selected general education classroom as a better educational placement setting for students with disabilities compared with resource room setting.

Parents of students without disabilities: The results in Table 8 indicate that a significantly higher proportion $(p<.001)$ of parents of students without disabilities selected separate facilities as the best educational placement setting for students with disabilities compared with any other educational placement setting. In addition, a significantly higher proportion $(p<.01)$ of parents of students without disabilities selected self-contained class as a better educational placement setting for students with disabilities compared with resource room setting. Moreover, it has been revealed that there was no significant difference $(p=.05)$ between the proportions of parents of students without disabilities who selected selfcontained class setting and those parents who selected general education classroom setting for students with disabilities. Similarly, there was no significant difference $(p=.05)$ between the proportions of parents of students without disabilities who selected resource room setting and those parents who selected general education classroom setting for students with disabilities.

Table 7

Results of the Chi-Square on the difference between percentages of parents

of students with disabilities responses for each pair of educational placement

\begin{tabular}{|c|c|c|c|c|c|c|}
\hline Setting & Observed N & Expected N & Residual & Chi-Square & $\mathrm{df}$ & Asymp. sig. \\
\hline Separate facilities & 77 & 65.0 & 12.0 & 4.431 & 1 & .035 \\
\hline Self-contained class & 53 & 65.0 & -12.0 & & & \\
\hline Total & 130 & & & & & \\
\hline Separate facilities & 113 & 74.5 & 38.5 & 25.252 & 1 & .000 \\
\hline Resource room & 36 & 74.5 & -38.5 & & & \\
\hline Total & 149 & & & & & \\
\hline Separate facilities & 77 & 64.5 & 12.5 & 4.845 & 1 & .028 \\
\hline General education & 52 & 64.5 & -12.5 & & & \\
\hline Total & 129 & & & & & \\
\hline Self-contained class & 53 & 39.5 & 13.5 & 9.228 & 1 & .002 \\
\hline Resource room & 26 & 39.5 & -13.5 & & & \\
\hline Total & 79 & & & & & \\
\hline Self-contained class & 53 & 52.5 & .5 & 0.010 & 1 & .922 \\
\hline General education & 52 & 52.5 & -.5 & & & \\
\hline Total & 105 & & & & & \\
\hline
\end{tabular}


Table 7

Results of the Chi-Square on the difference between percentages of parents

of students with disabilities responses for each pair of educational placement

\begin{tabular}{lllllll}
\hline Setting & Observed N & Expected N & Residual & Chi-Square & df & Asymp. sig. \\
\hline Resource room & 26 & 39.0 & -13.0 & 8.667 & 1 & .003 \\
General education & 52 & 39.0 & 13.0 & & & \\
Total & 78 & & & & & \\
\hline
\end{tabular}

Table 8

Results of the Chi-Square on the difference between percentages of parents of students without disabilities responses for each pair of educational placement

\begin{tabular}{|c|c|c|c|c|c|c|}
\hline Setting & Observed N & Expected N & Residual & Chi-Square & $\mathrm{Df}$ & Asymp.sig. \\
\hline Separate facilities & 154 & 119.0 & 35.0 & 20.588 & 1 & .000 \\
\hline Self-contained class & 84 & 119.0 & -35.0 & & & \\
\hline Total & 238 & & & & & \\
\hline Separate facilities & 154 & 104.5 & 49.5 & 46.895 & 1 & .000 \\
\hline Resource room & 55 & 104.5 & -49.5 & & & \\
\hline Total & 209 & & & & & \\
\hline Separate facilities & 154 & 111.0 & 43.0 & 33.315 & 1 & .000 \\
\hline General education & 68 & 111.0 & -43.0 & & & \\
\hline Total & 222 & & & & & \\
\hline Self-contained class & 84 & 69.5 & 14.5 & 6.050 & 1 & .014 \\
\hline Resource room & 55 & 69.5 & -14.5 & & & \\
\hline Total & 139 & & & & & \\
\hline Self-contained class & 84 & 76.0 & 8.0 & 1.684 & 1 & .194 \\
\hline General education & 68 & 76.0 & -8.0 & & & \\
\hline Total & 152 & & & & & \\
\hline Resource room & 55 & 61.5 & -6.5 & 1.374 & 1 & 241 \\
\hline General education & 68 & 61.5 & 6.5 & & & \\
\hline Total & 123 & & & & & \\
\hline
\end{tabular}

Students: The results in Table 9 indicate that a significantly higher proportion $(p<.001)$ of students selected separate facilities as the best educational placement setting for students with disabilities compared with any other educational placement setting. Moreover, a significantly higher proportion $(p<.01)$ of students preferred the self-contained class setting over the resource room setting for students with disabilities. On the other hand, the findings revealed no significant difference $(p=.05)$ between the proportion of students who selected self-contained class setting and those students who selected general education classroom setting. Finally, the findings indicate a significantly higher proportion $(p<.001)$ of students preferred general education classroom setting to the resource room setting for students with disabilities.
Question 5: What is the stakeholders' educational placement preference (separate facilities vs. regular school) for students with disabilities?

The binomial test was performed for each category of stakeholders' responses to examine the significance of the difference between the proportion of stakeholders who selected the regular school setting and the proportion of those who selected the separate facilities setting as the best educational placement setting for students with disabilities. The results of the binomial test are presented in Table 10. These results showed a significantly higher proportion $(\mathrm{p}<0.01)$ of stakeholders who preferred the regular school over the separate facilities setting for students with disabilities for all stakeholders'

Table 9

Results of the Chi-square on the difference between percentages of students' responses for each pair of educational placement

\begin{tabular}{lllllll}
\hline Setting & Observed N & Expected N & Residual & Chi-Square & Df & Asymp.sig. \\
\hline Separate facilities & 181 & 132.0 & 49.0 & 36.379 & 1 & .000 \\
Self-contained class & 83 & 132.0 & -49.0 & & & \\
Total & 264 & & & & & \\
Separate facilities & 181 & 114.0 & 67.0 & 78.754 & 1 & .000 \\
$\begin{array}{l}\text { Resource room } \\
\text { Total }\end{array}$ & 47 & 114.0 & -67.0 & & & \\
$\quad$ Separate facilities & 228 & & & & & \\
$\quad$ General education & 68 & 124.5 & 56.5 & 51.281 & & .000 \\
Total & 68 & 124.5 & -56.5 & & &
\end{tabular}


Table 9

Results of the Chi-square on the difference between percentages of students' responses for each pair of educational placement

\begin{tabular}{lllllll}
\hline Setting & Observed N & Expected N & Residual & Chi-Square & Df & Asymp.sig. \\
\hline Self-contained class & 83 & 65.0 & 18.0 & 9.969 & 1 & .002 \\
Resource room & 47 & 65.0 & -18.0 & & & \\
Total & 130 & & & & & \\
Self-contained class & 83 & 75.5 & 7.5 & 1.490 & 1 & .222 \\
General education & 68 & 75.5 & -7.5 & & & \\
Total & 151 & & & & & \\
Resource room & 47 & 57.5 & -10.5 & 3.835 & & .050 \\
General education & 68 & 57.5 & 10.5 & & & \\
Total & 115 & & & & & \\
\hline
\end{tabular}

categories, with the exception of two categories, i.e.; regular education teachers and students showed no significant differences in their preference.

Question 6: What is the stakeholders' educational placement preference (separate facilities vs. regular school) for each type of disability?

The binomial test was performed to examine the differences between the proportions of the stakeholders who selected the regular school option compared with those who selected the separate facilities as the best educational placement setting for each separate type of disability. The results of the binomial test are presented in Table 11. The findings indicate that the regular school was selected as a better educational placement setting in comparison with separate facilities by $78 \%$ of stakeholders for students with other health impairments, $77 \%$ for students with specific learning disabilities, $69 \%$ for students with speech and language disabilities, $61 \%$ for students with autism, $61 \%$ for students with hearing impairments, $59 \%$ for students with emotional and behavioral disabilities, $51 \%$ for students with physical disabilities, $51 \%$ students with visual impairments, and $50 \%$ for students with intellectual disabilities. The results also revealed that a significantly higher proportion $(p<.000)$ of stakeholders selected regular school as a better placement for each type of disability, with the exception of physical disabilities, visual impairments, and intellectual disabilities, which showed non-significant differences $(p=$ .05) between the proportion of stakeholders who selected the regular school and those who selected the separate facilities.

Table 10

Results of the binomial test for stakeholders' responses on educational placement (separate facilities \& regular school) for students with disabilities

\begin{tabular}{|c|c|c|c|c|c|}
\hline Type of disability & Response category & $\mathrm{N}$ & $\begin{array}{l}\text { Observed } \\
\text { prop. }\end{array}$ & $\begin{array}{l}\text { Test } \\
\text { prop. }\end{array}$ & $\begin{array}{l}\text { Exact sig. } \\
\text { (2-tailed) }\end{array}$ \\
\hline \multirow[t]{3}{*}{ Regular Teacher } & Separate Facilities & 303 & .48 & .50 & .359 \\
\hline & Regular School & 327 & .52 & & \\
\hline & Total & 630 & 1.00 & & \\
\hline \multirow[t]{3}{*}{ Special Education Teacher } & Separate Facilities & 94 & .42 & .50 & .019 \\
\hline & Regular School & 130 & .58 & & \\
\hline & Total & 224 & 1.00 & & \\
\hline \multirow[t]{3}{*}{ Social Worker } & Separate Facilities & 47 & .32 & .50 & .000 \\
\hline & Regular School & 100 & .68 & & \\
\hline & Total & 147 & 1.00 & & \\
\hline \multirow[t]{3}{*}{ Principal } & Separate Facilities & 113 & .39 & .50 & .000 \\
\hline & Regular School & 178 & .61 & & \\
\hline & Total & 291 & 1.00 & & \\
\hline \multirow[t]{3}{*}{ Parents of students with disabilities } & Separate Facilities & 77 & .37 & .50 & .000 \\
\hline & Regular School & 131 & .63 & & \\
\hline & Total & 208 & 1.00 & & \\
\hline \multirow[t]{3}{*}{ Parents of students without disabilities } & Separate Facilities & 154 & .43 & .50 & .006 \\
\hline & Regular School & 207 & .57 & & \\
\hline & Total & 361 & 1.00 & & \\
\hline \multirow[t]{3}{*}{ Student } & Separate Facilities & 181 & .48 & .50 & .411 \\
\hline & Regular School & 198 & .52 & & \\
\hline & Total & 379 & 1.00 & & \\
\hline
\end{tabular}


Table 11

Results of the binomial test of stakeholders' responses on educational placement setting (separate facilities \& regular school) for each type of disability

\begin{tabular}{|c|c|c|c|c|c|}
\hline Type of disability & Response category & $\mathrm{N}$ & $\begin{array}{l}\text { Observed } \\
\text { prop. }\end{array}$ & $\begin{array}{l}\text { Test } \\
\text { prop. }\end{array}$ & $\begin{array}{l}\text { Exact } \\
\text { sig. (2- } \\
\text { tailed) }\end{array}$ \\
\hline \multirow[t]{3}{*}{ Intellectual disability } & Separate facilities & 1114 & .50 & .50 & .784 \\
\hline & Regular school & 1128 & .50 & & \\
\hline & Total & 2242 & 1.00 & & \\
\hline \multirow[t]{3}{*}{ Autism } & Separate facilities & 877 & .39 & .50 & .000 \\
\hline & Regular school & 1364 & .61 & & \\
\hline & Total & 2241 & 1.00 & & \\
\hline \multirow[t]{3}{*}{ Emotional \& Behavioral disability } & Separate facilities & 909 & .41 & .50 & .000 \\
\hline & Regular school & 1331 & .59 & & \\
\hline & Total & 2240 & 1.00 & & \\
\hline \multirow[t]{3}{*}{ Hearing Impairment } & Separate facilities & 866 & .39 & .50 & .000 \\
\hline & Regular school & 1375 & .61 & & \\
\hline & Total & 2241 & 1.00 & & \\
\hline \multirow[t]{3}{*}{ Other Health Impairment } & Separate facilities & 495 & .22 & .50 & .000 \\
\hline & Regular school & 1747 & .78 & & \\
\hline & Total & 2242 & 1.00 & & \\
\hline \multirow[t]{3}{*}{ Specific Learning Disabilities } & Separate facilities & 523 & .23 & .50 & .000 \\
\hline & Regular school & 1718 & .77 & & \\
\hline & Total & 2241 & 1.00 & & \\
\hline \multirow[t]{3}{*}{ Visual Impairment } & Separate facilities & 1093 & .49 & .50 & .237 \\
\hline & Regular school & 1150 & .51 & & \\
\hline & Total & 2243 & 1.00 & & \\
\hline \multirow[t]{3}{*}{ Speech and Language Disability } & Separate facilities & 703 & .31 & .50 & .000 \\
\hline & Regular school & 1538 & .69 & & \\
\hline & Total & 2241 & 1.00 & & \\
\hline \multirow[t]{3}{*}{ Physical Disability } & Separate facilities & 1097 & .49 & .50 & .342 \\
\hline & Regular school & 1143 & .51 & & \\
\hline & Total & 2240 & 1.00 & & \\
\hline
\end{tabular}

Question 7: Does the stakeholders' educational placement preference for students with disabilities differ significantly according to the student's type of disability?

McNemar's test was performed to examine the differences between the proportion of the stakeholders who selected the regular school option compared with those who selected the separate facilities for each separate pair of various disabilities (health disabilities, specific learning disabilities, speech and language disabilities, autism, hearing impairments, emotional and behavioral disabilities, physical disabilities, visual impairments, and intellectual disabilities). The results of McNemar's test is summarized in Table 12.
The results suggest that the stakeholders' educational placement preference for students with disabilities differs significantly $(p<.000)$ according to the students' disabilities, with the exception of the following disabilities: other health impairment vs. specific learning disabilities, autism vs. emotional and behavioral disabilities, autism vs. hearing impairment, hearing impairment vs. emotional and behavioral disabilities, intellectual disability vs. visual impairment, intellectual disability vs. physical disability, and physical disability vs. visual impairment. The stakeholders' educational placement preference did not change significantly $(p>.05)$.

Table 12

Results of McNemar's test of stakeholders' responses on educational placement setting (separate facilities \& regular school) for students with disabilities

\begin{tabular}{|c|c|c|c|c|}
\hline Type of disability* & Pair differences \% & $\mathrm{N}$ & Chi-Square ${ }^{\star *}$ & Asymp. sig. \\
\hline ID - AUT & -11 & 2241 & 77.248 & .000 \\
\hline ID - EBD & -9 & 2239 & 51.585 & .000 \\
\hline ID - HI & -11 & 2240 & 78.418 & .000 \\
\hline ID - OHI & -28 & 2241 & 377.023 & .000 \\
\hline ID - SLD & -27 & 2240 & 361.475 & .000 \\
\hline ID - VI & -1 & 2242 & .492 & .483 \\
\hline ID - S-L & -19 & 2240 & 192.832 & .000 \\
\hline ID - PHD & -1 & 2239 & .319 & .572 \\
\hline AUT - EBD & 2 & 2239 & 1.538 & .215 \\
\hline
\end{tabular}


Table 12

Results of McNemar's test of stakeholders' responses on educational placement setting (separate facilities \& regular school) for students with disabilities

\begin{tabular}{|c|c|c|c|c|}
\hline Type of disability* & Pair differences \% & $\mathrm{N}$ & Chi-Square** & Asymp. sig. \\
\hline AUT - HI & 0 & 2240 & .136 & .712 \\
\hline AUT - OHI & -17 & 2240 & 181.451 & .000 \\
\hline AUT - SLD & -16 & 2239 & 156.247 & .000 \\
\hline AUT - VI & 11 & 2241 & 55.030 & .000 \\
\hline AUT - S-L & -8 & 2239 & 39.066 & .000 \\
\hline AUT - PHD & 10 & 2238 & 60.386 & .000 \\
\hline EBD - HI & -2 & 2240 & 2.413 & 120 \\
\hline EBD - OHI & -19 & 2240 & 210.060 & .000 \\
\hline EBD - SLD & -18 & 2239 & 180.485 & .000 \\
\hline EBD - VI & 8 & 2240 & 40.543 & .000 \\
\hline EBD - S-L & -10 & 2238 & 53.878 & .000 \\
\hline EBD - AUT - PHD & 8 & 2237 & 43.129 & .000 \\
\hline $\mathrm{HI}$ - OHI & -17 & 2241 & 189.875 & .000 \\
\hline HI - SLD & -16 & 2240 & 158.854 & .000 \\
\hline HI - VI & 10 & 2241 & 77.979 & .000 \\
\hline HI - S-L & -8 & 2239 & 40.885 & .000 \\
\hline HI - PHD & 10 & 2238 & 72.169 & .000 \\
\hline OHI - SLD & 1 & 2241 & 1.736 & 188 \\
\hline OHI - VI & 27 & 2242 & 395.132 & .000 \\
\hline OHI - S-L & 9 & 2240 & 68.449 & .000 \\
\hline OHI - PHD & 27 & 2239 & 400.445 & .000 \\
\hline SLD - VI & 26 & 2241 & 364.596 & .000 \\
\hline SLD - S-L & 8 & 2239 & 53.580 & .000 \\
\hline SLD - PHD & & 2238 & 345.495 & .000 \\
\hline VI - S-L & -18 & 2241 & 198.869 & .000 \\
\hline VI - PHD & 0 & 2240 & .023 & .880 \\
\hline S-L - PHD & 18 & 2240 & 211.574 & .000 \\
\hline
\end{tabular}

*ID (Intellectual Disability), AUT (Autism), EBD (Emotional and Behavioral Disability), HI (Hearing Impairment), OHI (Other Health Impairment), SLD (Specific Learning Disabilities), VI (Vision Impairment), L-D (Speech and language disability), PHD (Physical Disability)

${ }^{* *}$ Continuity Corrected

\section{Discussion}

The information provided by the Ministry of Education and the Ministry of Social Development (2015) revealed that 5,325 children with disabilities received educational services in Oman. Twenty nine percent of these children are enrolled in special education classes in public school and $71 \%$ are enrolled in special education schools or centers. In comparison, $95 \%$ of children with disabilities in the United States receive their education in regular schools and the remaining in separate settings (Giangreco, Smith, \& Pinckney 2006; Hocutt, 1996; U.S. Department of Education, 2014).

The data suggests that a very small number of Omani children with disabilities are receiving educational services; considering that WHO (2011) estimated about $15 \%$ of any population have a disability. This finding is consistent with the estimation of the percentage of children with disabilities who attend school in developing countries, which ranges from less than $1 \%$ to $10 \%$ (Peters, 2004; UNESCO, 2009).
The data also indicates that no special education services have been provided for children with disabilities in the general education classrooms so far. In comparison, $87 \%$ of children with disabilities in the United States are educated in the general education classroom setting (U.S. Department of Education, 2014).

Moreover, the data showed a separate and segregated special education system in Oman. Unfortunately, history shows that a separate and segregated education system was not successful in achieving inclusive schools in the U.S.A. (Lamport, Graves, \& Ward, 2012) and more likely will not in Oman.

The results of the current study also showed a significantly higher proportion of special education teachers, social workers, principals, parents of students with disabilities, and parents of students without disabilities preferred the regular school as a better setting than the proportion of those who preferred the separate facility settings for educating students with disabilities. However, there were no significant differences between the proportion of the regular education teachers and the propor- 
tion of the students who preferred regular school or the proportion of those who preferred the separate facilities. However, Byrnes, Sigafoos, Rickards, and Brown (2002) reported that $60.3 \%$ of students with hearing impairments from Australia preferred to be educated in their local school, not in a separate setting.

Further investigation into the stakeholders' preference of the educational settings (separate facilities, self-contained class, resource room, and general education) indicate the following: a) a significantly higher proportion of each category of stakeholder selected separate facilities as the best educational placement setting for students with disabilities compared with any other educational setting, with exception of the social workers, who preferred the self-contained class setting over the separate facilities setting, b) a significantly higher proportion of each category of stakeholder selected self-contained class as the best educational setting for students with disabilities compared with resource room and general education classroom settings, with the exception being the proportion of special education teachers, parents of students with disabilities, parents of students without disabilities and students who preferred the self-contained class, who did not differ significantly from the proportion of those who selected the general education classroom setting, and c) there were no significant differences between the proportion of each category of stakeholder who selected the resource room setting and the proportion of those stakeholders who selected the general education classroom setting, with the exception of a significantly higher proportion of social workers, parents of students with disabilities, and students, who preferred the general education classroom setting over the resource room setting. Similarly, Livingston, Reed, and Good (2001) found that principals from the state of Georgia, U.S.A, preferred the self-contained classroom in regular school as the best placement option for children with disabilities.

In addition, the results revealed that a significantly higher proportion of stakeholders selected the regular school as a better placement over separate facilities for educating students with the following disabilities: specific learning, other health impairment, speech and language, autism, hearing impairment, and emotional and behavioral. However, there were no significant differences between the proportion of stakeholders who selected the regular school as a better placement and the proportion of stakeholders who selected separate facilities for educating students with the following disabilities: physical, visual impairment, and intellectual.

Moreover, the findings suggest that the stakeholders' preference for educating students in the regular school setting versus a separate facility varied according to the type of disability. The order, from more likely to least likely, of the stakeholders' preference for educating students in a regular school setting versus a separate facility according to the type of disability is the following: a) other health impairment or specific learning disability, b) speech and language disability, c) autism, emotional and behavioral disability, or hearing impairment, and d) physical disability, visual impairment, or intellectual disability respectively. Finally, there were no significant differences in stakeholders' preference for educating students in the regular school setting versus a separate facility between the following disabilities: other health impairment vs. specific learning disabilities, autism vs. emotional and behavioral disabilities, autism vs. hearing impairment, hearing impairment vs. emotional and behavioral disabilities, intellectual disability vs. visual impairment, intellectual disability vs. physical disability, and physical disability vs. visual impairment. Similarly, TASH (2009) and UNESCO (2010) documented that the likelihood of educating students with disabilities in the general education setting varied with the type of disability.

Finally, a significant association between stakeholders' role and their preference of educational placement setting for students with disabilities was found. However, the findings revealed that there was no significant relationship between stakeholders' gender and educational settings preference.

\section{Recommendations}

Overall, the stakeholders in Oman support the education of children with disabilities in regular school. In spite of this, the implementation of inclusive education is a complicated process. Successful inclusive education requires restructuring the education system, resources, accessible schools, and competent staff with positive attitudes. It is fundamental to develop 
national policies and procedures that regulate and operationally define the following: special education services, the specific process of providing special education services, the rights of students with disabilities and their parents, definitions of each type of disability, and their eligibility criteria for special education.

In order to provide effective and efficient special education services in inclusive classrooms, the Ministry of Education must assure the availability of a sufficient number of special education teachers and support staff (psychologists, occupational therapists, physical therapists, and speech therapists). The availability also of qualified staff (administrators, supervisors, regular classroom teachers) in teaching students with disabilities is essential.

In addition, the availability of a continuum of placement options is necessary to meet the needs of all special education students. Finally, the availability of valid and reliable assessment instruments that measure academic, social, and emotional development, speech and language, adaptive behaviors, gross motor skills, fine motor skills are crucial for screening, determining eligibility, planning, progress monitoring, and evaluation.

\section{Acknowledgment}

The investigators would like to express their sincere appreciation to the Research Affairs at Sultan Qaboos University and the United Arab Emirates University for the financial support of this project under Grant \# SQU$\mathrm{UAEU} / 09 / 02$.

\section{References}

Ahsan, T., Sharma, U., \& Deppeler, M., (2012). Exploring pre-service teachers'

teaching-efficacy, attitudes and concerns about inclusive education in Bangladesh. International Journal of Whole Schooling, 8(2), 2-20.

Al-Balushi, T., Al-Badi, A., \& Ali, S. (2011). Prevalence of disability in Oman: statistics and challenges. Canadian Journal of Applied Sciences, 1(3), 81-96.

Avramidis, E., Balyliss, P., \& Burden, R. (2000). A survey into mainstream teachers' attitudes towards the inclusion of children with special educational needs in the ordinary school in one local educa- tion authority. Educational Psychology, 20(2), 191-211.

Avramidis, E., \& Norwich, B. (2002). Teachers' attitudes towards integration/inclusion: a

review of the literature. Eur. J. of Special Education, 17(2), 129-147.

Balboni, G. \& Pedrabissi, L. (2000). Attitudes of Italian teachers and parents toward

school inclusion of students with mental retardation: the role of experience. Education and Training in Mental Retardation and Developmental Disabilities, 35(2), 148-159.

Byrnes, L., Sigafoos, J., Rickards, F., \& Brown, P. (2002). Inclusion of students who are deaf or hard hearing in government schools in New South Wales, Australia: Development and implementation of a policy. Journal of Deaf Studies and Deaf Education, 7(3), 244-257.

Dyson, A., Howes, A., \& Roberts, B. (2004). What do we really know about inclusive schools? A systematic review of the research evidence. In D. Mitchell (Ed.) Special Educational Needs and Inclusive Education: Major themes in education. London: Routlege Falmer.

Emam, M., \& Hassan, H. (2011). Preschool and primary school teachers' attitudes towards inclusive education in Egypt: the role of experience and self-efficacy. Procedia-Social and Behavioral Sciences, 29, 976985.

Gannon, S., \& McGilloway, S. (2009). Children's attitudes toward their peers with Down syndrome in schools in rural Ireland: an exploratory study. European Journal of Special Needs Education, 24 (4), 455-463.

Georgiadi, M., Kalyva, E., Kourkoutas, E., \& Tsakiris,V. (2012). Young children's attitudes toward peers with intellectual disabilities: Effect of the type of school. Journal of Applied Research in Intellectual Disabilities, 25, 531-541.

Giangreco, F., Smith, C., \& Pinckney, E. (2006). Addressing the paraprofessional dilemma in an inclusive school: A program description. Research and Practice for Person with Severe Disabilities, 31(3), 215229. 
Gilmore, L., Campbell, J. \& Cuskelly, M. (2003). Developmental expectations, personality

stereotypes, and attitudes towards inclusive education: community and teacher views of Down Syndrome. International Journal of Disability, Development and Education, 50(1), 65-76.

Grove, K., \& Fisher, D. (1999). Entrepreneurs of meaning: Parents and the process of inclusive education. Remedial and Special Education, 20(4), 208-215

Haj Hussien, J., \& Al-Qaryouti., I. (2014). Regular education teachers' attitudes towards inclusion in Oman. Journal of Educational and Psychological Studies (JEPS), $8(4), 617-626$.

Haj Hussien, J., \& Al-Qaryouti, I. (2015a). Students' attitudes toward inclusive education in Oman, International Journal for research in Education, 37, 1-11.

Haj Hussien, J., \& Al-Qaryouti, I. (2015b). General Education Teachers' Perceived Self-Efficacy in Teaching Students with Disabilities in Oman AJIE Asian Journal of Inclusive Education, 3(1), 3-23.

Hocutt. A. (1996). Effectiveness of special education: Is placement the critical factor? The Future of Children Special Education for Students with Disabilities, 6(1), 77-102.

Hunt, P., \& McDonnell, J. (2007). Inclusive education. In Odom, S., Horner, R., Snell, M., \& Blacher, J. (Eds.) Handbook of developmental Disabilities (269-291). New York, NY: The Guilford Press.

Kauffman, J., Bantz, J., \& McCullough, J. (2002). Separate and Better: A special public school class for students with emotional and behavioral disorders. Exceptionality, 10(3), 149-170.

Kugelmass, J., \& Ainscow, M. (2004). Leadership for inclusion: a comparison of international practices. Journal of Research in Special Educational Needs, 4, 3, 133-141.

Lamport, M., Graves, L., \& Ward, A. (2012). Special students in inclusive classrooms: the impact of social interaction on educational outcomes for learners with emotional and behavioral disabilities. Europe- an Journal of Business and Social Sciences, 1(5), 54-69.

Livingston, M., Reed, T., \& Good, J. (2001). Attitudes of rural school principals toward inclusive practice and placements for students with severe disabilities. The Journal of Research for Educational Leaders, $1(1), 49-62$. http://www2.education.uiowa.edu/arch ives/jrel/fall01/Livingston_0102.pdf

Miller, M., Garriott, P., \& Mershon, D. (2005). Special education students' placement

preferences as shown in special education journals, Electronic Journal for Inclusive Education, 1 (9), 1-19.

Ministry of Education. (2008). Inclusive education in the state of Oman: national report of the Sultanateof Oman: Muscat.

http://www.ibe.unesco.org/National_Repor ts/ICE_2008/oman_NR08.pdf

Ministry of Education, General Administration of Learning, Special Education Administration. (2015). Inclusive education Statistics. Sultanate of Oman: Muscat.

Ministry of Social Development, General Administration of Persons with Disabilities Affairs, Rehabilitation Administration (2015). Sultanate of Oman: Muscat.

Morin, D., Crocker, A., Beaulieu-Bergeron, R., \& Caron, J. (2013). Validation of attitudes toward intellectual disability - ATTID questionnaire. Journal of Intellectual Disability Research, 57(3), 268-278.

Panagiotou, A., Evaggelinou, C., Doulkeridou, A., Mouratidou, K., \& Koidou, E. (2008).

Attitudes of $5^{\text {th }}$ and $6^{\text {th }}$ grade Greek students toward the inclusion of children with disabilities in physical education classes after a paralympic education program. European Journal of Adapted Physical Activity, 1(2), 31-43.

Papaioannou, C., Evaggelinou, C., \& Block, M. (2014). The effect of a disability campprogram on attitudes towards the inclusion of children in a summer sport and leisure activity camp. International Journal of Special Education, 29(1), 1-9. 
Patel, M., \& Rose, J. (2014). Students' attitudes towards individuals with an intellectual disability. Journal of Intellectual Disabilities, 18(1), 90-103.

Peters, S. (2004). Inclusive education: an EFA strategy for all children. World Bank. www.worldbank.org.

Rafferty, Y., Boettcher, C., \& Griffin, K. (2001). Benefits and risks of reverse inclusion for preschoolers with and without disabilities: Parents' perspectives. Journal of Early Intervention 24, 266-86.

Sari, H., Celikoz, N., \& Secer, Z. (2009). An analysis of pre-school teachers' and student teachers' attitudes to inclusion and their self-efficacy. International Journal of Special Education, 24(3), 29-43.

Semmel, M. (1986). Special education in the year2000 and beyond: A proposed actionagenda for addressing selected ideas. Reston, VA: The Council for Exceptional Children. (ERIC Document Reproduction Services No. LD276245).

Tafa, E., \& Manolitsis, G. (2003). Attitudes of Greek parents of typically developingkindergarten children towards inclusive education. European Journal of Special Needs Education, 18(2), 155-171.

TASH Congressional Briefing on Inclusive Education (2009). Inclusive Education and Implications for Policy: The State of the Art and the Promise.

http://www.edlawcenter.org/assets/file $\mathrm{s} / \mathrm{pdfs} /$ issues-special education/Inclusive\%20Education \%20and \%20I mplications\%20for\%20Policy.pdf

UNESCO. (2009). Towards inclusive education for children with disabilities: A guideline. Bangkok, Thailand. http://www.uis.unesco.org/Library/Do cuments/disabchild09-en.pdf

UNESCO. (2010) EFA Global Monitoring Report. Reaching the marginalized.http:// unesdoc.unesco.org/images /0018/001866/186606E.pdf

U.S. Department of Education, National Center for Education Statistics, Institute of Education Sciences. (2014). The condition of education 2014.

http://nces.ed.gov/pubs2014/2014083.p $\underline{\mathrm{df}}$

Villa, B., Thousand, J., Meyers, H. \& Navin, A. (1996). Teacher and administrative perceptions of heterogeneous education. Exceptional Children, 63, 29-45.

Wang, H. (2009). Should all students with special educational needs (SEN) be included in mainstream education provision? - A critical analysis. International Education Studies, 2(4), 154-161.

Weber, A.S. (2012). Inclusive education in the gulf cooperation council. Journal of Educational and Instructional Studies in the World, 2(2), 85-97.

WHO. (2011). World disability report. Geneva: WHO. 